\title{
CXV. COLLOIDS AND HAEMOLYSIS.
}

\author{
By JOHN WILLIAM PICKERING AND FRANK EDWARD TAYLOR. \\ From the Departments of Physiology and of Bacteriology, \\ University of London, King's College.
}

(Received August 5th, 1923.)

In the investigation of haemolytic phenomena the majority of experimenters have made use of washed corpuscles, which are more or less completely divested of the colloids of the plasma. During life, however, the erythrocytes of the blood are invariably associated with colloidal solutions. If, then, we are to gain any insight into the nature of haemolysis in the living organism, it appears essential to study the action of haemolytic substances also in association with colloids.

That serum exerts a protective action in haemolysis has been demonstrated by a number of observers. Moore, Wilson and Hutchinson [1909], Kerner [1910] and Sutherland and Mitra [1916] all recorded the inhibitory action of serum on haemolysis by sodium oleate, while Barker [1922] has noted the differences in the inhibitory power against haemolysis by this substance afforded by sera obtained from human blood during various forms of anaemia. Kuno [1918] found that the lysis produced by heating human erythrocytes was inhibited by the presence of human serum. Fenn [1922] stated that $0.1 \%$ of serum inhibits the haemolysis arising from the contact of erythrocytes with soiled glass. Ponder [1921, 1922, 1923] observed that serum inhibits the haemolytic action of urine and affords protection to human erythrocytes against haemolysis by a histamine-glycocholate mixture, by sodium taurocholate, by sodium glycocholate and by saponin.

Schmidt and Norman [1920] described the inhibition of the haemolysis produced by eosin in the presence of sunlight by serum, egg-white, caseinogen, edestin and "peptone" and stated that gelatin failed to restrain this photodynamic action. Pickering and Collins [1923] pointed out the protective action of isotonic gum-saline against the haemolysis of human erythrocytes at $13^{\circ}$ by $\mathrm{X}$-rays.

The objects of the present investigation are as follows: to ascertain the variations in the resistance to haemolysis of erythrocytes obtained from different individuals of the same species, both human and animal, and the effect of storage thereon: to enquire into the influence on haemolysis of various colloids, viz. gum acacia, gelatin, egg-white and sera, fresh and "inactivated": to investigate the influence of varying concentrations of saponin and of a naturally haemolytic serum on the speed and titre of haemolysis in the presence 
and absence of the colloids named and to enquire into possible modifications in the protection afforded by these colloids by alterations in the hydrion concentration in the media employed.

Eisler [1909] found that sugar inhibits specific haemolysis, that the addition of moderate amounts of various salts restores lysis, higher concentrations of the electrolytes again inducing inhibition. Purdy and Walbum [1922] found that certain metallic salts hasten haemolysis by saponin at some concentrations and show opposite effects at other concentrations. Periodicity or a socalled zone phenomenon has been described by Buchanan [1919] in the agglutination of meningococci by cerous nitrate, while Holker [1923] has demonstrated the occurrence of periodicity in the influence of increasing concentrations of sodium chloride on the opacity of human serum. Early in this investigation the influence of saponin dissolved in isotonic saline on haemolysis was found to be often periodic in nature. The effect of colloidal solutions on this periodicity was therefore studied.

\section{The Technique and Terms Employed.}

The tests for haemolysis were carried out in Dreyer's tubes both in the water-bath at $38^{\circ}$, controlled by a thermostat, and at room temperatures, which were read and noted at the time of each experiment. Haemolysis in the water-bath took place in the absence of light (except at the actual times of reading). The experiments at room temperatures were in the presence of diffuse daylight. The possible influence of daylight and of ultra-violet light on haemolysis by saponin and by the heterologous serum employed will be enquired into later. By "commencement" of haemolysis we mean the first change in opacity visible to the naked eye by transmitted light, by "completion" when the contents of the tube were free from residue, when similarly observed. In the tables " $\mathrm{H}$. begins" indicates the time of "commencement" of haemolysis; "H. ends" shows the time of "completion" of that process.

The "blood corpuscles employed were those of the sheep, guinea-pig, white rat and man. Except in the case of whole blood they were obtained by bleeding the animals into sterile glass tubes, defibrinating with glass beads, thrice washing in normal saline and centrifuging. $25 \%$ suspensions were made up in sterile tubes in $0.86 \% \mathrm{NaCl}$, dissolved in distilled water. The haemolysing agents used were saponin (Merck) and the serum of a rabbit which was haemolytic at $38^{\circ}$ to all the erythrocytes used, except those of the rabbit. Variations in the $p_{\mathrm{H}}$ of the protective colloids were made by rendering them neutral, faintly alkaline and faintly acid to litmus, by the addition of small quantities of $N / 100 \mathrm{HCl}$ and $N / 100 \mathrm{NaOH}$ respectively. The protective action in each case was then tested. Control experiments showed that the colloidal substances so treated were devoid of haemolytic action.

In each experiment the bulk of the haemolytic substance together with the protective colloid employed and the normal saline used for dilution was $1 \mathrm{cc}$. to which $0.004 \mathrm{cc}$. of a $25 \%$ suspension of the various corpuscles was added. 
Complete haemolysis is indicated by + , when more than half of the suspension is haemolysed \pm is used, when less than half $\mp$ is recorded. The letters N.C.H. imply nearly complete haemolysis. Each suspension undergoing haemolysis was compared with a standard suspension showing no haemolysis after centrifuging or settling out.

\section{Variations in the Resistance of Erythrocytes to Haemolysis.}

Considerable variations occur in the titre and speeds of haemolysis in individuals of the same species, but erythrocytes withdrawn under the same conditions on consecutive days from the same animal exhibit but little alteration in sensitiveness to haemolysis by saponin and by the haemolytic serum used. With human whole blood individual variations in sensitiveness to saponin are well marked, as shown in Table I. The temperature of haemolysis was $13^{\circ}$. Two readings (marked A and B) of the commencement and completion of haemolysis are shown for each concentration of saponin on corpuscles from bleedings from the same person taken at an interval of one week. In each case the reading $B$ was with blood withdrawn one week later than that used for reading A. Each bleeding was made in the afternoon.

Table I. Showing Individual Variations in the Sensitiveness of Human Blood to Haemolysis by Saponin.

\begin{tabular}{|c|c|c|c|c|c|}
\hline $\begin{array}{r}\text { Concentratio } \\
\text { in } 0.86\end{array}$ & $\begin{array}{l}\text { ns of saponin } \\
\% \mathrm{NaCl}\end{array}$ & $\begin{array}{c}1 / 10,000 \\
A\end{array}$ & $\underset{\mathrm{B}}{1 / 10,000}$ & $\begin{array}{c}1 / 20,000 \\
A\end{array}$ & $\begin{array}{c}1 / 20,000 \\
\text { B }\end{array}$ \\
\hline 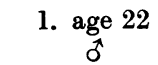 & $\left\{\begin{array}{l}H . \text { begins } \\
\text { H. ends }\end{array}\right.$ & $\begin{array}{lc}2^{\prime} & 0^{\prime \prime} \\
\mathbf{3} & \mathbf{3 0}\end{array}$ & $\begin{array}{ll}2^{\prime} & 10^{\prime \prime} \\
3 & 30\end{array}$ & $\begin{array}{l}3^{\prime} 30^{\prime \prime} \\
1030\end{array}$ & $\begin{array}{rl}3^{\prime} 30^{\prime \prime} \\
10 & 15\end{array}$ \\
\hline 2. age 23 & $\left\{\begin{array}{l}H . \text { begins } \\
\text { H. ends }\end{array}\right.$ & $\begin{array}{lr}2 & 30 \\
6 & 0\end{array}$ & $\begin{array}{ll}2 & 30 \\
5 & 55\end{array}$ & 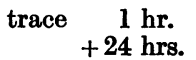 & $\begin{array}{l}-1 \mathrm{hr} . \\
+24 \mathrm{hrs} .\end{array}$ \\
\hline 3. age 26 & $\left\{\begin{array}{l}\text { H. begins } \\
\text { H. ends }\end{array}\right.$ & $\begin{array}{ll}2 & 30 \\
3 & 20\end{array}$ & $\begin{array}{ll}2 & 25 \\
3 & 30\end{array}$ & $\begin{array}{l} \pm 1 \mathrm{hr} . \\
+24 \mathrm{hrs} .\end{array}$ & $\begin{array}{l} \pm 1 \mathrm{hr} . \\
+24 \mathrm{hrs} .\end{array}$ \\
\hline 4. age 29 & $\left\{\begin{array}{l}H . \text { begins } \\
\text { H. ends }\end{array}\right.$ & $\begin{array}{rr}1 & 10 \\
4 & 0\end{array}$ & $\begin{array}{ll}2 & 0 \\
4 & 0\end{array}$ & $\begin{array}{ll} & -1 \mathrm{hr} . \\
\text { trace } & 24 \mathrm{hrs} .\end{array}$ & 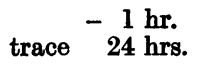 \\
\hline 5. age 30 & $\left\{\begin{array}{l}H . \text { begins } \\
\text { H. ends }\end{array}\right.$ & $\begin{array}{ll}0 & 55 \\
1 & 30\end{array}$ & $\begin{array}{rr}1 & 0 \\
1 & 35\end{array}$ & $\begin{array}{l}-1 \mathrm{hr} . \\
\pm 24 \mathrm{hrs} .\end{array}$ & trace $\begin{array}{r}1 \mathrm{hr} . \\
\pm 24 \mathrm{hrs} .\end{array}$ \\
\hline 6. age 31 & $\left\{\begin{array}{l}H . \text { begins } \\
\text { H. ends }\end{array}\right.$ & $\begin{array}{rr}1 & 40 \\
3 & 0\end{array}$ & $\begin{array}{lr}1 & 45 \\
3 & 0\end{array}$ & $\begin{array}{c}-1 \mathrm{hr} . \\
\text { N.C.H. } 24 \mathrm{hrs} .\end{array}$ & $\begin{array}{l}-1 \mathrm{hr} . \\
\text { N.C.H. } 24 \mathrm{hrs} .\end{array}$ \\
\hline 7. age 55 & $\left\{\begin{array}{l}\text { H. begins } \\
\text { H. ends }\end{array}\right.$ & $\begin{array}{ll}1 & 0 \\
4 & 0\end{array}$ & $\begin{array}{lr}1 & 0 \\
3 & 35\end{array}$ & $\begin{array}{l}-1 \mathrm{hr} . \\
\pm 24 \mathrm{hrs} .\end{array}$ & $\begin{array}{l}-1 \mathrm{hr} . \\
\pm 24 \mathrm{hrs} .\end{array}$ \\
\hline 8. age 26 & $\left\{\begin{array}{l}\mathrm{H} . \text { begins } \\
\mathrm{H} . \text { ends }\end{array}\right.$ & $\begin{array}{rr}3 & 30 \\
4 & 0\end{array}$ & $\begin{array}{rr}3 & 30 \\
4 & 5\end{array}$ & $\begin{array}{ll} & -1 \mathrm{hr} . \\
\text { trace } & 24 \mathrm{hrs} .\end{array}$ & -24 hrs. \\
\hline 9. age 28 & $\left\{\begin{array}{l}\text { H. begins } \\
\text { H. ends }\end{array}\right.$ & $\begin{array}{rr}2 & 0 \\
4 & 30\end{array}$ & $\begin{array}{ll}2 & 10 \\
4 & 30\end{array}$ & trace $\quad-\quad 1 \mathrm{hr}$. & $\begin{array}{l}\mp 1 \mathrm{hr} . \\
\mp 24 \mathrm{hrs} .\end{array}$ \\
\hline 10. age 35 & $\left\{\begin{array}{l}H . \text { begins } \\
H . \text { ends }\end{array}\right.$ & $\begin{array}{lr}2 & 30 \\
4 & 0\end{array}$ & $\begin{array}{ll}2 & 30 \\
4 & 10\end{array}$ & $\begin{array}{ll} & -1 \mathrm{hr} . \\
\text { trace } & 24 \mathrm{hrs} .\end{array}$ & $\begin{array}{l}\text { - } 1 \mathrm{hr} . \\
\mp 24 \mathrm{hrs} .\end{array}$ \\
\hline 11. $\underset{+}{\text { age }} 48$ & $\left\{\begin{array}{l}\mathrm{H} . \text { begins } \\
\text { H. ends }\end{array}\right.$ & $\begin{array}{lr}1 & 0 \\
1 & 30\end{array}$ & $\begin{array}{ll}1 & 10 \\
1 & 30\end{array}$ & $\begin{array}{ll} & -1 \mathrm{hr} . \\
\text { trace } & 24 \mathrm{hrs} .\end{array}$ & -24 hrs. \\
\hline 12. age 54 & $\left\{\begin{array}{l}\mathrm{H} . \text { begins } \\
\text { H. ends }\end{array}\right.$ & $\begin{array}{rr}2 & 0 \\
3 & 10\end{array}$ & $\begin{array}{ll}2 & 30 \\
3 & 10\end{array}$ & $\begin{array}{l}-1 \mathrm{hr} . \\
+24 \mathrm{hrs} .\end{array}$ & $\begin{array}{l}-1 \mathrm{hr} . \\
\pm 24 \mathrm{hrs} .\end{array}$ \\
\hline
\end{tabular}

The following may be noted:

(1) The speeds of haemolysis by saponin of whole blood taken from the same person at the interval of one week are remarkably constant. 
(2) The relatively rapid haemolysis of whole blood by a high concentration of saponin does not imply a relatively low resistance to lower concentrations of saponin. Thus the corpuscles of one individual (No. 11) which were completely haemolysed in $1^{\prime} 30^{\prime \prime}$ by $1 / 10,000$ saponin, exhibited incomplete haemolysis after exposure for 24 hours to $1 / 20,000$ saponin, whereas the corpuscles of another individual (No. 1) which were haemolysed in $3^{\prime} 30^{\prime \prime}$ by $1 / 10,000$ saponin, exhibited complete haemolysis after exposure for $10^{\prime} 30^{\prime \prime}$ to $1 / 20,000$ saponin. In an isolated case (blood from a male aged 25), 1/40,000 of saponin gave partial haemolysis in 2 hours and complete haemolysis in 24 hours.

(3) Similar variations in individual sensitiveness to haemolysis by saponin occur with the thrice washed corpuscles of man, the guinea-pig, white rat, sheep and rabbit, greater variations being found in the speed than in the titre of haemolysis of the corpuscles examined; those of the sheep appear to exhibit the least individual variations in sensitiveness to haemolysis by saponin and, in this connection, the high resistance exhibited by the erythrocytes of this animal to haemolysis by saponin may be recalled. The thrice washed corpuscles of the guinea-pig, which are hypersensitive to saponin, exhibit as marked individual variations in sensitiveness to haemolysis by that substance as does the whole blood of that animal or the whole blood or washed erythrocytes of man.

It was found that the resistance of sheep's corpuscles to saponin, as shown by the titre and speed of haemolysis, underwent little alteration when the erythrocytes were kept for two days in sterile tubes at room temperatures $\left(13^{\circ}-14^{\circ}\right)$ or for three days in an ice-chest. After these periods resistance is definitely lower as is shown by the next table.

\begin{tabular}{|c|c|c|c|c|c|c|c|}
\hline \multicolumn{2}{|c|}{$\begin{array}{c}\text { Concentrations of saponin dissolved } \\
\text { in } 0.86 \% \mathrm{NaCl}\end{array}$} & \multirow{2}{*}{$\begin{array}{l}1 / 800 \\
3^{\prime} 50^{\prime \prime} \\
440\end{array}$} & \multirow{2}{*}{$\begin{array}{rl}1 / 1600 \\
9^{\prime} & 30^{\prime \prime} \\
18 & 30\end{array}$} & \multirow{2}{*}{$\begin{array}{l}1 / 3200 \\
21^{\prime} 30^{\prime \prime} \\
3930\end{array}$} & \multirow{2}{*}{$\begin{array}{c}1 / 6400 \\
-24 \mathrm{hrs} .\end{array}$} & \multirow{2}{*}{$\begin{array}{l}1 / 12800 \\
-24 \text { hrs. }\end{array}$} & \multirow{2}{*}{$\begin{array}{l}1 / 25600 \\
-24 \mathrm{hrs} .\end{array}$} \\
\hline $\begin{array}{l}\text { resh erythrocytes } \\
\text { heep) }\end{array}$ & $\left\{\begin{array}{l}\text { H. begins } \\
\text { H. ends }\end{array}\right.$ & & & & & & \\
\hline $\begin{array}{l}\text { Erythrocytes kept } 4 \text { days } \\
\text { in ice-chest (sheep) }\end{array}$ & $\left\{\begin{array}{l}\text { H. begins } \\
\text { H. ends }\end{array}\right.$ & $\begin{array}{ll}2 & 0 \\
3 & 0\end{array}$ & $\begin{array}{ll}2 & 30 \\
4 & 15\end{array}$ & $\begin{array}{rr}8 & 0 \\
14 & 0\end{array}$ & $\begin{array}{l}12^{\prime} 0^{\prime \prime} \\
280\end{array}$ & $\begin{array}{ll}18^{\prime} & 0^{\prime \prime} \\
32 & 0\end{array}$ & $\begin{array}{l}-1 \mathrm{hr} . \\
\pm 24 \mathrm{hrs} .\end{array}$ \\
\hline
\end{tabular}

A similar lowering of resistance to haemolysis by saponin was observed when the erythrocytes of the guinea-pig, white rat and rabbit were kept, under the conditions named, for similar periods.

\section{Table III. Showing Deterioration in Resistance to Haemolysis by a Heterologous Serum due to Storage.}

\begin{tabular}{|c|c|c|c|c|c|}
\hline $\mathrm{s}$ of rabbit's serum & employed & $25 \%$ & $12.5 \%$ & $6 \cdot 25 \%$ & $3 \cdot 125 \%$ \\
\hline Fresh erythrocytes (sheep) & $\left\{\begin{array}{l}\mathrm{H} . \text { begins } \\
\text { H. ends }\end{array}\right.$ & $\begin{array}{l}2^{\prime} 0^{\prime \prime} \\
40\end{array}$ & $\begin{array}{l}16^{\prime} 0^{\prime \prime} \\
180\end{array}$ & $\begin{array}{l}-2 \mathrm{hrs} . \\
\pm 24 \mathrm{hrs} .\end{array}$ & $-24 \mathrm{hrs}$. \\
\hline $\begin{array}{l}\text { Erythrocytes kept } 4 \text { days at } 13^{\circ} \\
\text { (sheep) }\end{array}$ & $\left\{\begin{array}{l}\text { H. begins } \\
\text { H. ends }\end{array}\right.$ & $\begin{array}{c}\text { at once } \\
,\end{array}$ & $\begin{array}{rl}9 & 0 \\
15 & 0\end{array}$ & $\begin{array}{l}21^{\prime} 0^{\prime \prime} \\
420\end{array}$ & 3. \\
\hline
\end{tabular}

Similar results were obtained with fresh and "four day" guinea-pig's corpuscles, when the haemolysing agent was serum from the same rabbit. 


\section{The Protective Action of Gum Acacia.}

A $7 \%$ solution of gum acacia, dissolved in $0.86 \% \mathrm{NaCl}$, was used. One half of the fluid of the suspensions was of this material, the remainder being saponin, in the dilutions named, dissolved in isotonic saline. In the control experiments the suspensions were in $0.86 \% \mathrm{NaCl}$. The protective action of gum-saline against the haemolysis at $13^{\circ}$ by saponin of fresh sheep's corpuscles is usually very slight and may be absent. When the corpuscles have remained in sterile tubes in an ice-chest, excluded from daylight, the protective action of gum acacia is well marked at $13^{\circ}$ against certain concentrations of saponin, as is shown in Table IV.

\section{Table IV. Showing the Protection afforded by Gum-saline against the Haemolysis of Stored Erythrocytes by Saponin.}

\begin{tabular}{|c|c|c|c|c|c|c|}
\hline Concentrations of saponin used & $1 / 800$ & $1 / 1600$ & $1 / 3200$ & $1 / 12800$ & $1 / 25600$ & $1 / 51200$ \\
\hline $\begin{array}{l}\text { Sheep's erythrocytes sus- }\left\{\begin{array}{l}\mathrm{H} \text {. begins } \\
\text { pended in } 0.86 \% \mathrm{NaCl}\end{array} \text {. ends }\right.\end{array}$ & $\begin{array}{ll}2^{\prime} & 0^{\prime \prime} \\
3 & 0\end{array}$ & $\begin{array}{ll}2^{\prime} & 30^{\prime \prime} \\
4 & 15\end{array}$ & $\begin{array}{rl}8^{\prime} & 0^{\prime \prime} \\
14 & 0\end{array}$ & $\begin{array}{l}18^{\prime} 0^{\prime \prime} \\
330\end{array}$ & $\begin{array}{l}-1 \mathrm{hr} . \\
\pm 24 \mathrm{hrs}\end{array}$ & $\begin{array}{l}-24 \mathrm{hrs} \text {. } \\
\text { ace } 48 \mathrm{hrs} \text {. }\end{array}$ \\
\hline $\begin{array}{l}\text { Sheep's erythrocytes sus- } \begin{array}{l}H . \text { begins } \\
\text { oended in gum-saline }\end{array} \\
\text { H. ends }\end{array}$ & $\begin{array}{ll}2 & 0 \\
3 & 0\end{array}$ & $\begin{array}{rr}5 & 50 \\
12 & 0\end{array}$ & $\begin{array}{rr}8 & 0 \\
17 & 30\end{array}$ & $24 \mathrm{hrs}$. & -24 & $=0$ \\
\hline
\end{tabular}

Table $\mathrm{V}$ records the speeds of haemolysis of the fresh erythrocytes of the sheep at $38^{\circ}$, and of the corpuscles of the guinea-pig, white rat and rabbit, at room temperatures, by saponin dissolved in $0.86 \% \mathrm{NaCl}$ and by like concentrations of saponin in the presence of $50 \%$ of a $7 \%$ solution of gum acacia dissolved in $0.86 \% \mathrm{NaCl}$. The commercial gum acacia employed was faintly acid to litmus and contained salts of calcium.

Hitherto the appearance of periodicity, as illustrated by changes in the agglutination of erythrocytes, in the opacity of serum and in specific haemolysis, has been associated with variations in the concentration of the electrolytes present. Reference to Table $\mathrm{V}$ will show that periodicity occurs in the haemolysis of sheep's corpuscles at $38^{\circ}$ and at lower temperatures with the erythrocytes of the guinea-pig and white rat, when the suspensions are made and the saponin is dissolved in normal saline. In these cases the variant is the concentration of the saponin and not the total amount of electrolyte present.

That temperature may also be a factor in periodicity in haemolysis is illustrated by the fact that the phenomenon is frequently absent in the haemolysis of sheep's corpuscles by saponin at $13^{\circ}$ but is well marked at $38^{\circ}$.

It appears probable that periodicity in haemolysis, under the conditions named, is due to alterations in the local concentrations of electrolytes at the interfaces of the corpuscles by the varying concentrations of saponin present. If this is so, physical phenomena are involved in the inception of haemolysis by saponin.

With the erythrocytes of a guinea-pig suspended in normal saline the presence of $1 / 51,200$ of saponin caused relatively slow haemolysis accompanied by marked sedimentation. The presence of $1 / 102,400$ of saponin gave more rapid haemolysis and sedimentation was absent. The corpuscles of another guinea-pig exhibited slow haemolysis accompanied by sedimentation when 
Table V. Showing the Action of Gum-saline and the Occurrence of Periodicity in the Haemolysis of Fresh Erythrocytes by Saponin.

\begin{tabular}{|c|c|c|c|c|c|c|}
\hline \multicolumn{2}{|c|}{ Concentrations of saponin used } & \multirow{2}{*}{$\begin{array}{c}1 / 6400 \\
\text { complete } \\
\text { in } 60^{\prime \prime}\end{array}$} & $1 / 12800$ & $1 / 25600$ & \multirow{2}{*}{$\begin{array}{l}1 / 51200 \\
30^{\prime} 0^{\prime \prime} \\
\mp 24 \mathrm{hrs} .\end{array}$} & \multirow{2}{*}{$\begin{array}{l}1 / 102400 \\
-48 \mathrm{hrs} .\end{array}$} \\
\hline $\begin{array}{l}\text { Sheep's erythrocytes in } \\
0.86 \% \mathrm{NaCl} \text { at } 38^{\circ}\end{array}$ & $\left\{\begin{array}{l}\text { H. begins } \\
\text { H. ends }\end{array}\right.$ & & $\begin{array}{ll}2^{\prime} & 0^{\prime \prime} \\
3 & 0\end{array}$ & $\begin{array}{c}8^{\prime} 0^{\prime \prime} \\
\mp \quad 2 \mathrm{hrs} . \\
\pm 24 \mathrm{hrs} .\end{array}$ & & \\
\hline $\begin{array}{l}\text { Sheep's erythrocytes in } \\
50 \% \text { gum-saline at } 38^{\circ}\end{array}$ & $\left\{\begin{array}{l}\text { H. begins } \\
\text { H. ends }\end{array}\right.$ & $\begin{array}{l}\text { complete } \\
\text { in } 1^{\prime} 50^{\prime \prime}\end{array}$ & $\begin{array}{ll}2 & 30 \\
7 & 30\end{array}$ & $\begin{array}{c}21^{\prime} \quad 0^{\prime \prime} \\
\pm 2 \quad \text { hrs. } \\
\text { N.C.H. } \\
24 \text { hrs. }\end{array}$ & $\begin{array}{l}-120^{\prime} \\
\text { slight } \\
24 \mathrm{hrs} .\end{array}$ & -48 hrs. \\
\hline $\begin{array}{l}\text { Guinea-pig's corpuscles in } \\
0.86 \% \mathrm{NaCl} \text { at } 13^{\circ}\end{array}$ & $\left\{\begin{array}{l}\text { H. begins } \\
\text { H. ends }\end{array}\right.$ & $\begin{array}{ll}0^{\prime} & 50^{\prime \prime} \\
1 & 30\end{array}$ & $\begin{array}{ll}4 & 30 \\
8 & 30\end{array}$ & $\begin{array}{cc}7^{\prime} & 30^{\prime \prime} \\
13 & 0\end{array}$ & $\begin{array}{rl}6^{\prime} & 30^{\prime \prime} \\
11 & 30\end{array}$ & $\begin{array}{l}12^{\prime} 45^{\prime \prime} \\
1540\end{array}$ \\
\hline $\begin{array}{l}\text { Guinea-pig's corpuscles in } \\
50 \% \text { gum-saline at } 13^{\circ}\end{array}$ & $\left\{\begin{array}{l}\text { H. begins } \\
\text { H. ends }\end{array}\right.$ & $\begin{array}{ll}0 & 50 \\
1 & 30\end{array}$ & $\begin{array}{ll}5 & 50 \\
8 & 30\end{array}$ & $\begin{array}{l}10 \quad 0 \\
-2 \mathrm{hrs} . \\
\pm 24 \mathrm{hrs} .\end{array}$ & $\begin{array}{l}100 \\
-120^{\prime} \\
\pm 24 \mathrm{hrs} .\end{array}$ & $-24 \mathrm{hrs}$. \\
\hline $\begin{array}{l}\text { White rat's corpuscles in } \\
.86 \% \mathrm{NaCl} \text { at } 13^{\circ}\end{array}$ & $\left\{\begin{array}{l}\text { H. begins } \\
\text { H. ends }\end{array}\right.$ & $\begin{array}{ll}0 & 30 \\
1 & 20\end{array}$ & $\begin{array}{ll}1 & 30 \\
2 & 20\end{array}$ & $\begin{array}{l}1^{\prime} 30^{\prime \prime} \\
230\end{array}$ & $\begin{array}{cc}3^{\prime} & 55^{\prime \prime} \\
28 & 0\end{array}$ & $\begin{array}{r}27^{\prime} 0^{\prime \prime} \\
+1200 \\
+24 \text { hrs. }\end{array}$ \\
\hline $\begin{array}{l}\text { White rat's c } \\
0 \% \text { gum-se }\end{array}$ & $\left\{\begin{array}{l}H . \text { begins } \\
\text { H. ends }\end{array}\right.$ & $\begin{array}{ll}0 & 30 \\
1 & 30\end{array}$ & $\begin{array}{rr}4 & 0 \\
55 & 0\end{array}$ & $\begin{array}{l}1215 \\
\mp 24 \mathrm{hrs} .\end{array}$ & -48 hrs. & $\begin{array}{l}-24 \mathrm{hrs} . \\
\mp 48 \mathrm{hrs} .\end{array}$ \\
\hline $\begin{array}{l}\text { Rabbit's corpuscles in } \\
0.86 \% \mathrm{NaCl} \text { at } 14^{\circ}\end{array}$ & $\left\{\begin{array}{l}\text { H. begins } \\
\text { H. ends }\end{array}\right\}$ & \}at once & $\begin{array}{lr}\mathbf{l}^{\prime} & 0 \\
\mathbf{l}^{1} & 40\end{array}$ & $\begin{array}{rr}\mathbf{2} & 0 \\
\mathbf{3} & \mathbf{0}\end{array}$ & 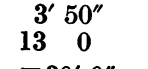 & $\begin{array}{rl}7^{\prime} & 0^{\prime \prime} \\
14 & 0\end{array}$ \\
\hline $\begin{array}{l}\text { cabbit's corpuscles in } \\
0 \% \text { gum-saline at } 14^{\circ}\end{array}$ & $\left\{\begin{array}{l}H . \text { begins } \\
\text { H. ends }\end{array}\right.$ & $\begin{array}{l}1^{\prime} 50^{\prime \prime} \\
210\end{array}$ & $\begin{array}{lr}4 & 30 \\
5 & 0\end{array}$ & $\begin{array}{ll}10 & 20 \\
12 & 30\end{array}$ & $\begin{array}{l}\mp 30^{\prime} 0^{\prime \prime} \\
+4 \mathrm{hrs}\end{array}$ & hrs. \\
\hline Conce & in used & $1 / 204800$ & $1 / 409600$ & $1 / 819200$ & $1 / 1638400$ & $1 / 3276800$ \\
\hline $\begin{array}{l}\text { heep's erythrocytes in } \\
.86 \% \mathrm{NaCl} \text { at } 38^{\circ}\end{array}$ & $\left\{\begin{array}{l}\mathrm{H} . \text { begins } \\
\mathrm{H} . \text { ends }\end{array}\right.$ & $\begin{array}{l}2^{\prime} 30^{\prime \prime} \\
3 \quad 30\end{array}$ & $\begin{array}{ll}2^{\prime} & 0^{\prime \prime} \\
\mathbf{3} & \mathbf{3 0}\end{array}$ & $\begin{array}{l}54^{\prime} \quad 0^{\prime \prime} \\
\pm 24 \mathrm{hrs}\end{array}$ & -24 hrs. & $-24 \mathrm{hrs}$ \\
\hline $\begin{array}{l}\text { heep's erythrocytes in } \\
\% \text { gum-saline at } 38^{\circ}\end{array}$ & $\left\{\begin{array}{l}H . \text { begins } \\
H . \text { ends }\end{array}\right.$ & $\begin{array}{l}16.0 \\
\text { N.C.H. } \\
24 \text { hrs. }\end{array}$ & $\begin{array}{ll}3 & 0 \\
8 & 0\end{array}$ & $\begin{array}{l}3^{\prime} 50^{\prime \prime} \\
90\end{array}$ & $\begin{array}{l}-120^{\prime} 0^{\prime \prime} \\
\text { trace } \\
24 \mathrm{hrs} .\end{array}$ & $\begin{array}{l}\text { trace } \\
24 \mathrm{hrs} .\end{array}$ \\
\hline $\begin{array}{l}\text { uinea-pig's corpuscles in } \\
86 \% \mathrm{NaCl} \text { at } 13^{\circ}\end{array}$ & $\left\{\begin{array}{l}\text { H. begins } \\
\text { H. ends }\end{array}\right.$ & 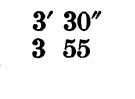 & $\begin{array}{ll}1 & 20 \\
3 & 20\end{array}$ & $\begin{array}{ll}4 & 45 \\
8 & 35\end{array}$ & $\begin{array}{c}40^{\prime} 0^{\prime \prime} \\
\text { N.C.H. } \\
24 \text { hrs. }\end{array}$ & $\mp 24$ hrs. \\
\hline $\begin{array}{l}\text { uinea-pig's corpuscles in } \\
0 \% \text { gum-saline at } 13^{\circ}\end{array}$ & $\left\{\begin{array}{l}\text { H. begins } \\
\text { H. ends }\end{array}\right.$ & $\begin{array}{l}-2 \mathrm{hrs} . \\
\text { 干2 } 24 \mathrm{hrs} .\end{array}$ & $\begin{array}{l}-2 \mathrm{hrs} . \\
\text { 干 } 24 \mathrm{hrs} .\end{array}$ & $-24 \mathrm{hrs}$ & -24 hrs. & -24 hrs. \\
\hline $\begin{array}{l}\text { Vhite rat's corpuscles in } \\
86 \% \mathrm{NaCl} \text { at } 13^{\circ}\end{array}$ & $\left\{\begin{array}{l}\mathrm{H} . \text { begins } \\
\mathrm{H} . \text { ends }\end{array}\right.$ & $\begin{array}{l}28^{\prime} \quad 0^{\prime \prime} \\
\pm 24 \text { hrs. }\end{array}$ & $\begin{array}{c}\mathbf{7}^{\prime} \quad 0^{\prime \prime} \\
\text { N.C.H. } \\
24 \text { hrs. }\end{array}$ & $\begin{array}{l}-60^{\prime} \quad 0^{\prime \prime} \\
\pm 24 \mathrm{hrs}\end{array}$ & $\begin{array}{l}-60^{\prime} \quad 0^{\prime \prime} \\
\pm 24 \mathrm{hrs}\end{array}$ & $\begin{array}{l}46^{\prime} 0^{\prime \prime} \\
\mp 600 \\
+24 \mathrm{hrs} .\end{array}$ \\
\hline $\begin{array}{l}\text { hite rat's corpuscles in } \\
\% \text { gum-saline at } 13^{\circ}\end{array}$ & $\left\{\begin{array}{l}\text { H. begins } \\
\text { H. ends }\end{array}\right.$ & $\begin{array}{l}-24 \mathrm{hrs} . \\
+48 \mathrm{hrs} .\end{array}$ & $\begin{array}{l}-24 \mathrm{hrs} . \\
+48 \mathrm{hrs} .\end{array}$ & $-48 \mathrm{hrs}$. & $-48 \mathrm{hrs}$ & $-48 \mathrm{hrs}$ \\
\hline $\begin{array}{l}36 \% \text { corpuscles in } \\
36 \% \mathrm{NaCl} \text { at } 14^{\circ}\end{array}$ & $\left\{\begin{array}{l}\text { H. begins } \\
\text { H. ends }\end{array}\right.$ & -48 hrs. & -48 hrs. & " & $"$ & $"$ \\
\hline $\begin{array}{l}\text { corpuscles in } \\
\mathrm{m} \text {-saline at } 14^{\circ}\end{array}$ & $\left\{\begin{array}{l}\text { H. begins } \\
\text { H. ends }\end{array}\right.$ & & $"$ & $"$ & " & $"$ \\
\hline
\end{tabular}

$1 / 102,400$ of saponin was present. With $1 / 204,800$ of saponin haemolysis was very rapid and sedimentation was absent. With $1 / 1,638,400$ haemolysis was very slow but sedimentation was absent. Sedimentation of the corpuscles of the guinea-pig was also observed in the presence of gum with concentrations of saponin varying from $1 / 51,200$ to $1 / 102,400$ with corpuscles from different animals, the sedimentation always corresponding with relatively slow haemolysis. With higher titres of saponin sedimentation appeared slight or absent. Sedimentation was not observed when gelatin or egg-white was substituted for gum.

The fresh corpuscles of the sheep at $38^{\circ}$, in the presence of gum-saline, exhibit periodic inhibition of haemolysis by saponin at different concentra- 
tions of the latter substance than when the gum is absent. For example, the presence of gum afforded marked protection against $1 / 25,600$ and $1 / 51,200$ of saponin and protection was also afforded against $1 / 204,800$ of saponin, yet with $1 / 819,200$ of that substance haemolysis was slow with the erythrocytes suspended in normal saline but very rapid with those (from the same animal) which were suspended in gum-saline. With $1 / 102,400$ of saponin inhibition of haemolysis occurred with both saline and gum suspensions. A zone phenomenon may be marked in the haemolysis of the corpuscles of the guinea-pig at $13^{\circ}$ by saponin dissolved in normal saline, but may be only slightly evident when corpuscles from the same animal are suspended in gum-saline. With the corpuscles of the white rat periodicity in haemolysis by saponin was found to be almost absent in presence of gum (see Table V). In the case of the rabbit it was not found either with protected or unprotected corpuscles, and it was noted that the protection afforded by gum against haemolysis by saponin is greater with the corpuscles of the rabbit than with those of the white rat, guinea-pig or sheep.

That individual variations occur in the appearance of periodicity in the haemolytic action of saponin is shown by Table VI.

Table VI.

Individual Variations in the Periodicity in Haemolysis by Saponin.

\begin{tabular}{|c|c|}
\hline Animal type & $\begin{array}{l}\text { Temp. of } \\
\text { haemolysis }\end{array}$ \\
\hline Sheep & $13^{\circ}$ \\
\hline " & $13^{\circ}$ \\
\hline " & $13^{\circ}$ and $38^{\circ}$ \\
\hline Räbit & $13^{\circ}$ and $38^{\circ}$ \\
\hline Guinea-pig & $\begin{array}{lll}13^{\circ} & 38^{\circ} \\
13^{\circ} & , & 16^{\circ}\end{array}$ \\
\hline 3 & $38^{\circ}$ \\
\hline " & $13^{\circ}$ \\
\hline Whit & ${ }_{13}^{\circ}$ \\
\hline & $13^{\circ}$ \\
\hline
\end{tabular}

Condition of erythrocytes
fresh in $0.86 \% \mathrm{NaCl}$
3rd day in $0.86 \% \mathrm{NaCl}$
fresh in gum-saline
3rd day in gum-saline
fresh and 3rd day in $0.86 \% \mathrm{NaCl}$
fresh in $0.86 \% \mathrm{NaCl}$ gum-saline
" gum-saline
" g
" $0.86 \%$ NaCl
" gum-saline

Proportion of animals with corpuscles which exhibited periodicity

\begin{tabular}{|c|c|c|c|}
\hline & & & 5 \\
\hline & 3 & , & 5 \\
\hline each & 10 & & 10 \\
\hline & 14 & , & 15 \\
\hline each & 0 & ", & b \\
\hline " & 0 & ", & 5 \\
\hline & 2 & , & 12 \\
\hline & 4 & $"$ & 5 \\
\hline & 3 & " & \\
\hline & & 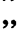 & \\
\hline & 0 & , & \\
\hline
\end{tabular}

Gum saline also protects the fresh erythrocytes of the guinea-pig and sheep against the haemolytic action of fresh rabbit's serum at $38^{\circ}$. (The serum employed was also haemolytic to the corpuscles of the sheep at $38^{\circ}$.)

\section{Table VII. Showing the Protective Action of Gum-saline against Haemolysis by a Heterologous Serum.}

\begin{tabular}{|c|c|c|c|c|c|c|c|c|}
\hline \multicolumn{2}{|c|}{$\begin{array}{c}\text { Proportions of rabbit's serum } \\
\text { present }\end{array}$} & \multirow{2}{*}{$\begin{array}{c}1 / 2 \\
\text { at once }\end{array}$} & \multirow{2}{*}{$\begin{array}{ll}1 / 4 \\
2^{\prime} & 0^{\prime \prime} \\
3 & 0\end{array}$} & \multirow{2}{*}{$\begin{array}{c}1 / 8 \\
3^{\prime} 30^{\prime \prime} \\
\mp 2 \mathrm{hrs} \\
+24 \mathrm{hrs} .\end{array}$} & \multirow{2}{*}{\multicolumn{2}{|c|}{$\begin{array}{c}1 / 16 \\
-24 \text { hrs. }\end{array}$}} & \multirow{2}{*}{\multicolumn{2}{|c|}{$\begin{array}{c}1 / 32 \\
-24 \text { hrs. }\end{array}$}} \\
\hline $\begin{array}{l}\text { Unprotected guinea- } \\
\text { pig's corpuscles }\end{array}$ & $\left\{\begin{array}{l}\mathrm{H} . \text { begins } \\
\mathrm{H} . \text { ends }\end{array}\right\}$ & & & & & & & \\
\hline $\begin{array}{l}\text { Guinea-pig's corpuscles } \\
\text { protected by gum }\end{array}$ & $\left\{\begin{array}{l}\text { H. begins } \\
\text { H. ends }\end{array}\right.$ & $\begin{array}{l}1^{\prime} 50^{n} \\
70\end{array}$ & $\begin{array}{rr}56 & 0 \\
123 & 0\end{array}$ & -24 hrs. & -24 & " & -24 & \\
\hline $\begin{array}{l}\text { Unprotected sheep's } \\
\text { corpuscles }\end{array}$ & $\left\{\begin{array}{l}\mathrm{H} . \text { begins } \\
\mathrm{H} . \text { ends }\end{array}\right\}$ & at once & $\begin{array}{ll}2 & 0 \\
4 & 0\end{array}$ & $\begin{array}{ll}6^{\prime} & 30^{\prime \prime} \\
8 & 30\end{array}$ & $\begin{array}{l}-2 \\
\pm 24\end{array}$ & ", & $\begin{array}{l}-2 \\
\pm 24\end{array}$ & \\
\hline $\begin{array}{l}\text { Sheep's corpuscles pro- } \\
\text { ected by gum }\end{array}$ & $\left\{\begin{array}{l}\text { H. begins } \\
\text { H. ends }\end{array}\right\}$ & ce & $\begin{array}{ll}4 & 0 \\
9 & 0\end{array}$ & $\begin{array}{ll}120 & 0 \\
148 & 0\end{array}$ & $\begin{array}{l}-2 \\
\pm 24\end{array}$ & ", & $\begin{array}{l}-24 \\
-24\end{array}$ & \\
\hline
\end{tabular}




\section{The Influence on Haemolysis of Alteration in the Hydrion Concentration of Saponin Solutions.}

Isotonic solutions of saponin were prepared which were respectively neutral, faintly alkaline and faintly acid to litmus. Table VIII illustrates the speed and titre of haemolysis of the erythrocytes of the guinea-pig and rabbit when exposed to these solutions at a temperature of $14^{\circ}$.

Table VIII. Showing the Titre and Speed of Haemolysis by Saponin in Neutral, faintly Alkaline and Acid Solutions.

\begin{tabular}{|c|c|c|c|c|c|c|c|}
\hline Concentrations of sap & onin used & $1 / 12800$ & $1 / 25600$ & $1 / 51200$ & $1 / 102400$ & $1 / 204800$ & $1 / 409600$ \\
\hline $\begin{array}{l}\text { Guinea-pig's corpuscles } \\
\text { in neutral saponin }\end{array}$ & $\left\{\begin{array}{l}\text { H. begins } \\
\text { H. ends }\end{array}\right.$ & $\begin{array}{lr}2^{\prime} & 0^{\prime \prime} \\
5 & 30\end{array}$ & $\begin{array}{ll}2^{\prime} 30^{\prime \prime} \\
5 & 30\end{array}$ & $\begin{array}{ll}11^{\prime} & 0^{\prime \prime} \\
57 & 0\end{array}$ & -2 hrs. & $\begin{array}{l}22^{\prime} 0^{\prime \prime} \\
\mp 2 \mathrm{hrs} .\end{array}$ & -2 hrs. \\
\hline $\begin{array}{l}\text { Guinea-pig's corpuscles } \\
\text { in alkaline saponin }\end{array}$ & $\left\{\begin{array}{l}\text { H. begins } \\
\text { H. ends }\end{array}\right\}$ & at once & $\begin{array}{ll}0 & 30 \\
0 & 50\end{array}$ & $\begin{array}{ll}2 & 0 \\
5 & 0\end{array}$ & $\begin{array}{l}16^{\prime} 30^{\prime \prime} \\
\pm 2 \text { hrs. }\end{array}$ & $22^{\prime} 0^{\prime \prime}$ & , \\
\hline $\begin{array}{l}\text { Guinea-pig's corpuscles } \\
\text { in acid saponin }\end{array}$ & $\left\{\begin{array}{l}\text { H. begins } \\
\text { H. ends }\end{array}\right\}$ & at once & $\begin{array}{ll}0 & 30 \\
0 & 55\end{array}$ & $\begin{array}{ll}2 & 10 \\
3 & 45\end{array}$ & $\begin{array}{ll}3^{\prime} & 40^{\prime \prime} \\
6 & 50\end{array}$ & $\begin{array}{l}110 \\
\mp 2 \mathrm{hrs}\end{array}$ & ", \\
\hline $\begin{array}{l}\text { Guinea-pig's corpuscles } \\
\text { in neutral saponin }\end{array}$ & $\left\{\begin{array}{l}\text { H. begins } \\
\text { H. ends }\end{array}\right.$ & $\begin{array}{l}0^{\prime} 40^{\prime \prime} \\
130\end{array}$ & $\begin{array}{ll}2 & 40 \\
7 & 50\end{array}$ & $\begin{array}{rr}9 & 0 \\
18 & 0\end{array}$ & -2 hrs. & -2 hrs. & -2 hrs. \\
\hline $\begin{array}{l}\text { Guinea-pig's corpuscles } \\
\text { in alkaline saponin }\end{array}$ & $\left\{\begin{array}{l}\text { H. begins } \\
\text { H. ends }\end{array}\right.$ & $\begin{array}{ll}0 & 10 \\
0 & 30\end{array}$ & $\begin{array}{ll}0 & 40 \\
1 & 50\end{array}$ & $\begin{array}{ll}1 & 10 \\
2 & 10\end{array}$ & $\begin{array}{rl}8^{\prime} 30^{\prime \prime} & \\
24 & 30\end{array}$ & ", & " \\
\hline $\begin{array}{l}\text { Guinea-pig's corpuscles } \\
\text { in acid saponin }\end{array}$ & $\left\{\begin{array}{l}\text { H. begins } \\
\text { H. ends }\end{array}\right.$ & $\begin{array}{ll}0 & 30 \\
0 & 45\end{array}$ & $\begin{array}{ll}0 & 40 \\
1 & 30\end{array}$ & $\begin{array}{ll}2 & 50 \\
4 & 50\end{array}$ & $-2 \mathrm{hrs}$ & , & ", \\
\hline $\begin{array}{l}\text { Rabbit's corpuscles in } \\
\text { neutral saponin }\end{array}$ & $\left\{\begin{array}{l}\text { H. begins } \\
\text { H. ends }\end{array}\right.$ & $\begin{array}{ll}0 & 50 \\
1 & 10\end{array}$ & $\begin{array}{ll}1 & 50 \\
3 & 10\end{array}$ & $\begin{array}{ll}2 & 10 \\
6 & 50\end{array}$ & $\begin{array}{rl}7^{\prime} & 0^{\prime \prime} \\
20 & 0\end{array}$ & $"$ & ", \\
\hline $\begin{array}{l}\text { Rabbit's corpuscles in } \\
\text { alkaline saponin }\end{array}$ & $\left\{\begin{array}{l}\text { H. begins } \\
\text { H. ends }\end{array}\right\}$ & at once & $\begin{array}{ll}0 & 10 \\
0 & 40\end{array}$ & $\begin{array}{lr}0 & 35 \\
1 & 0\end{array}$ & $\begin{array}{rr}4 & 40 \\
17 & 40\end{array}$ & $\begin{array}{l}20^{\prime} \\
40^{\prime \prime} \\
49\end{array}$ & $\begin{array}{l}30^{\prime} \quad 0^{\prime \prime} \\
\mp 2 \mathrm{hrs} .\end{array}$ \\
\hline $\begin{array}{l}\text { Rabbit's corpuscles in } \\
\text { acid saponin }\end{array}$ & $\left\{\begin{array}{l}\text { H. begins } \\
\text { H. ends }\end{array}\right.$ & $\begin{array}{ll}0^{\prime} & 40^{\prime \prime} \\
0 & 45\end{array}$ & $\begin{array}{ll}1 & 10 \\
1 & 40\end{array}$ & $\begin{array}{ll}1 & 30 \\
2 & 20\end{array}$ & $\begin{array}{rr}5 & 50 \\
18 & 0\end{array}$ & $\begin{array}{l}170 \\
\text { trace } \\
2 \text { hrs. }\end{array}$ & -2 hrs. \\
\hline
\end{tabular}

Table VIII shows that faintly alkaline and faintly acid saponin are more haemolytic at $14^{\circ}$ than is neutral saponin. Like results were obtained when the temperature was $38^{\circ}$. Periodicity in haemolysis by saponin was not observed when the saponin was either faintly alkaline or faintly acid to litmus, even with corpuscles which exhibited periodicity in haemolysis by neutral saponin.

\section{The Effects of Altering the Hydrion Concentration of the Protective Colloids.}

Table IX shows the variations in the protection afforded by isotonic gelatin against the haemolysis of fresh erythrocytes of the guinea-pig by saponin at $14^{\circ}$ when the added gelatin is made neutral, faintly alkaline and faintly acid to litmus by the addition of hydrochloric acid and sodium hydroxide respectively.

The substitution of gum-saline for isotonic gelatin yields similar results; the gum which is faintly acid to litmus being more protective than gum which is faintly alkaline or neutral. 
Table IX. Showing the Protection against Saponin afforded

by Neutral, Alkaline and Acid Gelatin.

\begin{tabular}{|c|c|c|c|c|c|c|c|c|c|c|c|}
\hline \multicolumn{2}{|c|}{$\begin{array}{l}\text { Concentrations of } \\
\text { saponin used }\end{array}$} & \multirow{2}{*}{$\begin{array}{l}1 / 12800 \\
1^{\prime} 50^{\prime \prime} \\
255\end{array}$} & \multirow{2}{*}{\multicolumn{2}{|c|}{$\begin{array}{c}1 / 25600 \\
4^{\prime} 50^{\prime \prime} \\
1230\end{array}$}} & \multirow{2}{*}{\multicolumn{2}{|c|}{$\begin{array}{c}1 / 51200 \\
6^{\prime} 40^{\prime \prime} \\
1210\end{array}$}} & \multirow{2}{*}{$\begin{array}{l}1 / 102400 \\
53^{\prime} 0^{\prime \prime} \\
1000^{0}\end{array}$} & \multirow{2}{*}{$\begin{array}{l}1 / 204800 \\
2^{\prime} 30^{\prime \prime} \\
310\end{array}$} & \multirow{2}{*}{$\begin{array}{l}1 / 409600 \\
1^{\prime} 30^{\prime \prime} \\
230\end{array}$} & \multirow{2}{*}{ 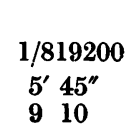 } & \multirow{2}{*}{$\begin{array}{c}1 / 1638400 \\
40^{\prime} 0^{\prime \prime} \\
\mp \quad 2 \mathrm{hrs} .\end{array}$} \\
\hline $\begin{array}{l}\text { Unprotected } \\
\text { erythrocytes }\end{array}$ & $\left\{\begin{array}{l}\text { H. begins } \\
\text { H. ends }\end{array}\right.$ & & & & & & & & & & \\
\hline $\begin{array}{l}\text { Erythrocytes in } \\
50 \% \text { neutral } \\
\text { gelatin }\end{array}$ & $\left\{\begin{array}{l}\text { H. begins } \\
\text { H. ends }\end{array}\right.$ & $\begin{array}{ll}3 & 0 \\
7 & 0\end{array}$ & $\begin{array}{l}32 \\
47\end{array}$ & $\begin{array}{l}0 \\
0\end{array}$ & $\begin{array}{r}68 \\
110\end{array}$ & $\begin{array}{l}0 \\
0\end{array}$ & $\begin{array}{rl}96 & 0 \\
122 & 0\end{array}$ & $-48 \mathrm{hrs}$. & $-48 \mathrm{hrs}$. & $\begin{array}{l}\mp 24 \mathrm{hrs} . \\
+48 \mathrm{hrs} .\end{array}$ & $-48 \mathrm{hrs}$. \\
\hline $\begin{array}{l}\text { Frythrocytes in } \\
50 \% \text { alkaline } \\
\text { gelatin }\end{array}$ & $\begin{array}{l}\text { H. begins } \\
\text { H. ends }\end{array}$ & $\begin{array}{ll}2 & 40 \\
7 & 10\end{array}$ & $\begin{array}{l}18 \\
36\end{array}$ & $\begin{array}{l}\mathbf{0} \\
\mathbf{0}\end{array}$ & $\begin{array}{l}30 \\
47\end{array}$ & $\begin{array}{l}\mathbf{0} \\
\mathbf{0}\end{array}$ & $\begin{array}{rl}66 & 0 \\
120 & 0\end{array}$ & " & " & -48 hrs. & " \\
\hline $\begin{array}{l}\text { Erythrocytes in } \\
50 \% \text { acid } \\
\text { gelatin }\end{array}$ & $\begin{array}{l}\text { H. begins } \\
\text { H. ends }\end{array}$ & $\begin{array}{lr}1 & 50 \\
5 & 0\end{array}$ & $\begin{array}{l}8 \\
\mp 2 \\
+24\end{array}$ & $\begin{array}{l}\text { o } \\
\text { hrs. } \\
\text { hrs. }\end{array}$ & $\begin{array}{l}-2 \\
\mp 4\end{array}$ & hrs. & $48 \mathrm{hrs}$. & " & " & " & " \\
\hline
\end{tabular}

In Table $\mathbf{X}$ is shown the protective power of neutral alkaline and acid gum against haemolysis of guinea-pig's erythrocytes by rabbit's serum at $38^{\circ}$.

Table X. Showing the Protection against Haemolysis by a Heterologous Serum afforded by Neutral, Alkaline and Acid Gum.

Proportions of rabbit's serum

\begin{tabular}{|c|c|c|c|c|c|c|c|}
\hline employed & $1 / 2$ & & $/ 4$ & $1 / 8$ & $1 / 16$ & $1 / 3$ & \\
\hline $\begin{array}{l}\text { Unprotected erythro- } \\
\text { cytes }\end{array}\left\{\begin{array}{l}\mathrm{H} . \text { begins } \\
\mathrm{H} . \text { ends }\end{array}\right.$ & $\begin{array}{c}\text { at once } \\
\text {, }\end{array}$ & & $\begin{array}{l}30^{\prime \prime} \\
20\end{array}$ & $\begin{array}{cc}2^{\prime} & 50^{\prime \prime} \\
26 & 0\end{array}$ & $\begin{array}{l}30^{\prime} 0^{\prime \prime} \\
\mp 2 \mathrm{hrs} .\end{array}$ & $\begin{array}{r}-2 \\
+4\end{array}$ & hrs, \\
\hline 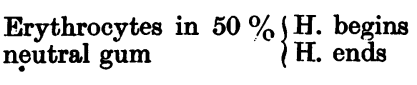 & $\begin{array}{lc}1^{\prime} & 30^{\prime \prime} \\
6 & 0\end{array}$ & $\begin{array}{l}16 \\
32\end{array}$ & $\begin{array}{l}\mathbf{0} \\
\mathbf{0}\end{array}$ & $\begin{array}{l}50 \quad 0 \\
\mp 2 \mathrm{hrs}\end{array}$ & $\begin{array}{l}+4 \\
100^{\prime} 0^{\prime \prime \prime} \\
\pm 24 \mathrm{hrs} .\end{array}$ & -24 & " \\
\hline 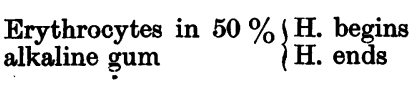 & $\begin{array}{rr}4 & 30 \\
26 & 0\end{array}$ & $\begin{array}{l}18 \\
\mathbf{3 4}\end{array}$ & $\begin{array}{l}\mathbf{0} \\
\mathbf{0}\end{array}$ & $\begin{array}{l}60^{\prime} 0^{\prime \prime \prime} \\
\pm 2 \mathrm{hrs} \\
+24\end{array}$ & $\begin{array}{l}116^{\prime} 30^{\prime \prime} \\
\pm 24 \mathrm{hrs}\end{array}$ & & " \\
\hline $\begin{array}{l}\text { Erythrocytes in } 50 \%\left\{\begin{array}{l}\mathrm{H} \text {. begins } \\
\text { acid gum ends }\end{array}\right.\end{array}$ & $\begin{array}{lr}1 & 50 \\
7 & 0\end{array}$ & $\begin{array}{r}56 \\
123\end{array}$ & $\begin{array}{l}\mathbf{0} \\
\mathbf{0}\end{array}$ & " & -2 & -24 & , \\
\hline
\end{tabular}

Table XI illustrates the variations in the protective power of $50 \%$ of egg-white, when untreated by reagents and respectively faintly alkaline and faintly acid to litmus, against the haemolysis of the corpuscles of the guineapig by saponin at $14^{\circ}$.

\section{Table XI. Showing the Protection afforded against Saponin by Natural,} Alkaline and Acid Egg-white.

\begin{tabular}{|c|c|c|c|c|c|c|}
\hline \multicolumn{2}{|c|}{ Concentrations of saponin used } & $1 / 6400$ & $1 / 12800$ & $1 / 25600$ & $1 / 51200$ & $1 / 102400$ \\
\hline Unprotected erythrocytes & $\left\{\begin{array}{l}\text { H. begins } \\
\text { H. ends }\end{array}\right.$ & $\begin{array}{l}0^{\prime} 50^{\prime \prime} \\
130\end{array}$ & $\begin{array}{l}2^{\prime} 40^{\prime \prime} \\
430\end{array}$ & $\begin{array}{l}4^{\prime} \mathbf{3 0} \\
\mathbf{7} \mathbf{3 0}\end{array}$ & $\begin{array}{l}8^{\prime} 30^{\prime \prime} \\
1250\end{array}$ & $\begin{array}{l}2^{\prime} 45^{\prime \prime} \\
545\end{array}$ \\
\hline $\begin{array}{l}\text { Erythrocytes in untreated } \\
\text { egg-white }\end{array}$ & $\left\{\begin{array}{l}\mathrm{H} . \text { begins } \\
\mathrm{H} . \text { ends }\end{array}\right.$ & $\begin{array}{ll}0 & 50 \\
1 & 30\end{array}$ & $\begin{array}{ll}2 & 30 \\
4 & 50\end{array}$ & $\begin{array}{l}60 \quad 0 \\
\pm 24 \mathrm{hrs}\end{array}$ & -24 hrs. & $-24 \mathrm{hrs}$ \\
\hline $\begin{array}{l}\text { Erythrocytes in alkaline } \\
\text { egg-white }\end{array}$ & $\left\{\begin{array}{l}\text { H. begins } \\
\text { H. ends }\end{array}\right.$ & $\begin{array}{rr}1 & 0 \\
1 & 30\end{array}$ & $\begin{array}{lr}2 & 50 \\
5 & 0\end{array}$ & -24 hrs. & $"$ & $"$ \\
\hline $\begin{array}{l}\text { Frythrocytes in acid } \\
\text { egg-white }\end{array}$ & $\left\{\begin{array}{l}\text { H. } \text { begins } \\
\text { H. ends }\end{array}\right\}$ & at once & $\begin{array}{lr}1 & 0 \\
1 & 30\end{array}$ & $\begin{array}{l}2^{\prime} \\
80^{\prime \prime} \\
8\end{array}$ & $\begin{array}{ll}6^{\prime} & 0^{\prime \prime} \\
60 & 0\end{array}$ & -24 hrs. \\
\hline \multicolumn{2}{|c|}{ Concentrations of saponin used } & $1 / 204800$ & $1 / 409600$ & $1 / 819200$ & $1 / 1638400$ & \\
\hline Unprotected erythrocytes & $\left\{\begin{array}{l}H . \text { begins } \\
H . \text { ends }\end{array}\right.$ & 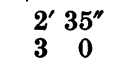 & $\begin{array}{l}\mathbf{l}^{\prime} 20^{\prime \prime} \\
220\end{array}$ & $\begin{array}{l}4^{\prime} 45^{\prime \prime} \\
830\end{array}$ & $\begin{array}{l}40^{\prime} 0^{\prime \prime} \\
\text { N.C.H. } 24 \mathrm{hrs}\end{array}$ & \\
\hline $\begin{array}{l}\text { Erythrocytes in untreated } \\
\text { egg-white }\end{array}$ & $\left\{\begin{array}{l}\text { H. begins } \\
\text { H. ends }\end{array}\right.$ & -24 hrs. & -24 hrs. & -24 hrs. & -24 hrs. & \\
\hline $\begin{array}{l}\text { Erythrocytes in alkaline } \\
\text { egg-white }\end{array}$ & $\left\{\begin{array}{l}H . \text { begins } \\
\text { H. ends }\end{array}\right.$ & " & " & ", & $"$ & \\
\hline $\begin{array}{l}\text { Erythrocytes in acid } \\
\text { egg-white }\end{array}$ & $\left\{\begin{array}{l}\text { H. begins } \\
\text { H. ends }\end{array}\right.$ & " & " & " & $"$ & \\
\hline
\end{tabular}


It will be noted that the protection afforded against haemolysis by saponin is greatest when the egg-white is in faintly alkaline solution and is least in faintly acid solution, untreated solutions occupying an intermediate position. The protection afforded by acid egg-white is however considerable. Periodicity in the action of the saponin was exhibited by the unprotected corpuscles, but appeared absent when egg-white was present. The contrast with the behaviour of gelatin in acid and alkaline solutions should be noted (vide Table IX). In this connection, it is noteworthy that Bayliss [1906] found that egg-white protects Congo red against the action of electrolytes in alkaline solution but exerts an opposite effect in acid solution.

When the haemolytic agency is the serum of the rabbit (at $38^{\circ}$ ) and the protective colloid is $50 \%$ of egg-white the results with guinea-pig's corpuscles are different.

\section{Table XII. Showing Protection by Natural, Alkaline and Acid}

Egg-white against Haemolysis by a Heterologous Serum.

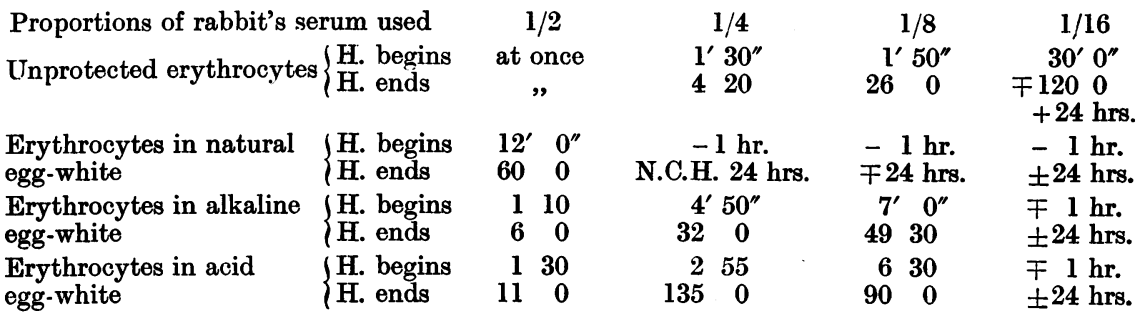

Similar results to those recorded in Tables XI and XII were found when white rat's corpuscles were substituted for those of the guinea-pig. The erythrocytes of the rabbit exposed to saponin in the presence of acid, alkaline and untreated egg-white and gelatin respectively gave results similar to, but less marked than, those obtained with the corpuscles of the guinea-pig. A serum haemolytic to rabbit's corpuscles was not available.

Table XIII. Showing Protection by Fresh and "Inactivated" Rabbit's Serum against Haemolysis by Saponin.

\begin{tabular}{|c|c|c|c|c|c|c|c|c|}
\hline \multicolumn{2}{|c|}{ Concentrations of saponin used } & \multicolumn{2}{|c|}{$1 / 400$} & $1 / 800$ & \multirow{2}{*}{$\begin{array}{l}1 / 1600 \\
6^{\prime} 30^{\prime \prime} \\
9 \\
9\end{array}$} & \multirow{2}{*}{$\begin{array}{l}1 / 3200 \\
11^{\prime} \quad 0^{\prime \prime} \\
14 \quad 10\end{array}$} & \multirow{2}{*}{$\begin{array}{l}1 / 6400 \\
20^{\prime} 0^{\prime \prime} \\
27 \\
30\end{array}$} & \multirow{2}{*}{$\begin{array}{l}1 / 12800 \\
45^{\prime} 0^{\prime \prime} \\
\pm 24 \mathrm{hrs}\end{array}$} \\
\hline $\begin{array}{l}\text { Unprotected sheep's } \\
\text { corpuscles }\end{array}$ & $\left\{\begin{array}{l}\text { H. begins } \\
\text { H. ends }\end{array}\right.$ & $\mathbf{1}^{\prime}$ & $\begin{array}{l}30^{\prime \prime} \\
30\end{array}$ & $\begin{array}{ll}4^{\prime} & 0^{\prime \prime} \\
6 & 30\end{array}$ & & & & \\
\hline $\begin{array}{l}\text { Corpuscles protected by } \\
\text { fresh serum }\end{array}$ & $\left\{\begin{array}{l}\text { H. begins } \\
\text { H. ends }\end{array}\right.$ & $\begin{array}{r}8 \\
12\end{array}$ & $\begin{array}{l}0 \\
0\end{array}$ & $\begin{array}{ll}14 & 0 \\
16 & 0\end{array}$ & $\begin{array}{l}-1 \mathrm{hr} . \\
\text { N.C.H. } \\
24 \mathrm{hrs} .\end{array}$ & $-24 \mathrm{hrs}$. & $-24 \mathrm{hrs}$. & -24 hrs. \\
\hline $\begin{array}{l}\text { Corpuscles protected by, } \\
\text { serum "inactivated" by } \\
\text { storage }\end{array}$ & & $\begin{array}{l}14 \\
48\end{array}$ & $\begin{array}{l}0 \\
0\end{array}$ & $\begin{array}{l}-1 \mathrm{hr} . \\
\text { trace } \\
24 \mathrm{hrs} .\end{array}$ & hrs. & " & " & " \\
\hline $\begin{array}{l}\text { Corpuscles protected by } \\
\text { serum "inactivated" by } \\
\text { heating to } 56^{\circ}\end{array}$ & & $\begin{array}{l}13 \\
48\end{array}$ & $\begin{array}{l}0 \\
0\end{array}$ & $\begin{array}{l}\text { trace } \\
1 \mathrm{hr} . \\
\text { trace }\end{array}$ & " & $"$ & $"$ & $"$ \\
\hline
\end{tabular}

The Protective Action of Certain Sera.

Table XIII shows the protection afforded by $50 \%$ of rabbit's serum, when fresh and "inactivated," by heating to $56^{\circ}$ and by storage, against the haemo- 
lysis of sheep's corpuscles at $11.5^{\circ}$ by saponin. The fresh serum employed was haemolytic to sheep's corpuscles at $38^{\circ}$.

Table XIV shows the protection afforded by $50 \%$ of rabbit's serum, when fresh and "inactivated," either by heating to $56^{\circ}$ or by storage, against the haemolysis of rabbit's corpuscles at $14^{\circ}$ by saponin.

Table XIV. Showing Protection by Fresh and "Inactivated" Rabbit's Serum against Haemolysis by Saponin.

\begin{tabular}{|c|c|c|c|c|c|c|c|}
\hline Concentrations of sapo & onin used & $1 / 3200$ & $1 / 6400$ & $1 / 12800$ & $1 / 25600$ & $1 / 51200$ & $1 / 102400$ \\
\hline Unprotected rabbit's & $\{\mathrm{H}$. begins & at once & at once & $1^{\prime} 0^{\prime \prime}$ & $1^{\prime} 5^{\prime \prime}$ & $2^{\prime} 50^{\prime \prime}$ & $6^{\prime} 40^{\prime \prime}$ \\
\hline erythrocytes & $\{$ H. ends & & & 140 & 140 & & 130 \\
\hline $\begin{array}{l}\text { Rabbit's erythrocytes } \\
\text { in fresh serum }\end{array}$ & $\left\{\begin{array}{l}\text { H. begins } \\
\text { H. ends }\end{array}\right.$ & $\begin{array}{l}11^{\prime} 30^{\prime \prime} \\
14 \quad 0\end{array}$ & $\begin{array}{l}\text { F24 hrs. } \\
+48 \text { hrs. }\end{array}$ & -48 hrs. & -48 hrs. & -48 hrs. & -48 hrs. \\
\hline $\begin{array}{l}\text { Rabbit's erythrocytes } \\
\text { in serum "inactivated" } \\
\text { by storage }\end{array}$ & $\left\{\begin{array}{l}\text { H. begins } \\
\text { H. ends }\end{array}\right.$ & -48 hrs. & -48 hrs. & , & ," & ", & 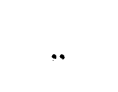 \\
\hline $\begin{array}{l}\text { Rabbit's erythrocytes } \\
\text { in serum "inactivated" } \\
\text { by heating }\end{array}$ & , $\mathrm{H}$. & $\begin{array}{l}-24 \mathrm{hrs} . \\
\mp 48 \mathrm{hrs} .\end{array}$ & " & $"$ & ", & " & "' \\
\hline
\end{tabular}

The following may be noted concerning the protection afforded by sera against the haemolysis of washed erythrocytes by saponin.

(1) A fresh serum, which is haemolytic at $38^{\circ}$, may be protective at room temperatures $\left(13^{\circ}-14^{\circ}\right)$ against haemolysis by saponin. Thus a serum may be protective at a low temperature and haemolytic at body temperature.

(2) The sera of the rabbit, guinea-pig and white rat, when "inactivated" either by heating to $56^{\circ}$ or by storage, are protective against the haemolysis by saponin of rabbit's, guinea-pig's and white rat's corpuscles at room and body temperatures. The "inactivated" sera exhibit rather greater protective qualities than do the fresh sera.

(3) Rabbit's serum, fresh and "inactivated" either by storage or heating (obtained from an animal haemolytic to the sheep), protects rabbit's corpuscles against haemolysis by saponin at $13^{\circ}$ and at $38^{\circ}$. A like protection is afforded by the serum (fresh and "inactivated") of the white rat to the corpuscles of the white rat at $13^{\circ}$ and at $38^{\circ}$. Horse serum, when "inactivated" by storage, is powerfully protective against the haemolysis by saponin at $13^{\circ}$ and at $38^{\circ}$ of the corpuscles of the sheep, guinea-pig and white rat.

Table XV shows the protective power of $50 \%$ horse serum ("inactivated" by storage) against the haemolytic action of fresh rabbit's serum at $38^{\circ}$ on the corpuscles of the guinea-pig and the sheep.

Table XV. Showing Protection by "Inactivated" Horse Serum against Haemolysis by Rabbit's Serum.

\begin{tabular}{|c|c|c|c|c|}
\hline Proportion of rabbit's serum used & $1 / 2$ & $1 / 4$ & $1 / 8$ & $1 / 16$ \\
\hline 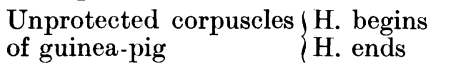 & at once & $\begin{array}{ll}2^{\prime} & 0^{\prime \prime} \\
3 & 0\end{array}$ & $\begin{array}{l}3^{\prime} 30^{\prime \prime} \\
-24 \mathrm{hrs}\end{array}$ & $\begin{array}{l}46^{\prime} 30^{\prime \prime} \\
\mp 24 \mathrm{hrs} .\end{array}$ \\
\hline 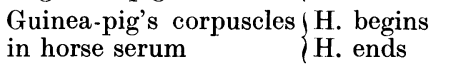 & $\begin{array}{rl}2^{\prime} & 0^{\prime \prime} \\
23 & 0\end{array}$ & trace 24 hrs. & -24 hrs. & -24 hrs. \\
\hline $\begin{array}{l}\text { Unprotected corpuscles }\left\{\begin{array}{l}\mathrm{H} . \text { begins } \\
\text { of the sheep }\end{array}\right. \\
\mathrm{H} \text {. ends }\end{array}$ & $\begin{array}{l}\text { at once } \\
\quad,\end{array}$ & $\begin{array}{lr}2^{\prime} & 0^{\prime \prime} \\
4 & 30\end{array}$ & $\begin{array}{ll}6^{\prime} & 30^{\prime \prime} \\
8 & 30\end{array}$ & $\begin{array}{l}-120^{\prime} 0^{\prime \prime} \\
\pm 24 \mathrm{hrs}\end{array}$ \\
\hline $\begin{array}{l}\text { Sheep's corpuscles in } \\
\text { horse serum }\end{array}\left\{\begin{array}{l}\text { H. begins } \\
\text { H. ends }\end{array}\right.$ & $\begin{array}{l}60^{\prime} 0^{\prime \prime} \\
\text { N.C.H. } 2 \text { hrs. }\end{array}$ & -24 hrs. & -24 hrs. & -24 hrs. \\
\hline
\end{tabular}


Preliminary experiments with fresh serum of the rabbit and with the "inactivated" serum of the horse indicate that their respective protective qualities are modified by rendering the media of the suspensions faintly acid and faintly alkaline to litmus. It is proposed, however, to defer the publication of this work until more experiments have been conducted.

\section{Summary and Conclusion.}

(1) Individual variations occur in the sensitiveness to haemolysis by saponin in whole human blood and in the washed erythrocytes of man, the guinea-pig, white rat, sheep and rabbit.

(2) The individual variations in sensitiveness described are due to variations in the condition of the erythrocytes and not to differences in any plasma or serum which may be adherent to them.

(3) Relatively rapid haemolysis by a high concentration of saponin does not imply a relatively low resistance to lower concentrations of saponin.

(4) The resistance of the erythrocytes of the sheep, guinea-pig, white rat and rabbit to haemolysis by saponin is lowered by keeping the corpuscles in normal saline for longer than three days in sterile tubes at either room temperature or that of an ice-chest.

(5) Periodicity is exhibited in the haemolysis of sheep's corpuscles at $38^{\circ}$ by saponin dissolved in $0.86 \% \mathrm{NaCl}$. A similar periodicity occurs in the haemolysis at room temperatures of the corpuscles of the guinea-pig and white rat by saponin dissolved in normal saline.

(6) The occurrence of periodicity in haemolysis by saponin may be modified by alterations in the temperature of the corpuscles.

(7) The presence of gum acacia alters the concentrations at which periodic inhibition of haemolysis occurs in the action of saponin on the erythrocytes of the sheep. Periodicity in haemolysis by saponin appears to be absent when the corpuscles of the white rat and guinea-pig are suspended in gum-saline.

(8) Individual variations occur in the appearance or absence of periodicity in haemolysis by saponin. Periodicity in saponin haemolysis appears to be absent when rabbit's erythrocytes are used.

(9) The association of sedimentation of corpuscles with the exhibition of periodicity in haemolysis is described.

(10) Isotonic gum-saline, isotonic gelatin, egg-white, the "inactivated" serum of the horse, the fresh serum of the rabbit and that "inactivated" either by storage or by heating to $56^{\circ}$ protect in varying degrees the erythrocytes of the sheep, white rat, rabbit, and guinea-pig against haemolysis by saponin at room temperatures $\left(13^{\circ}-14^{\circ}\right)$.

(11) The serum of a rabbit, which at $38^{\circ}$ was haemolytic to the corpuscles of the sheep, protects the erythrocytes of the latter animal against haemolysis by saponin at $13^{\circ}$ to $14^{\circ}$. The same serum may thus, at different temperatures, be haemolytic and protective respectively. 
(12) "Inactivated" serum is more highly protective than is the fresh serum of the same animal.

(13) Gum-saline, isotonic gelatin, egg-white and "inactivated" horse serum protect the erythrocytes of the guinea-pig against the haemolytic action of the serum of the rabbit at body temperature.

(14) The protective action of gum acacia, gelatin, egg-white and of certain sera against haemolysis by saponin or by a haemolytic serum is modified by altering the hydrion concentration of the respective colloids. Faintly acid egg-white is less protective against saponin than is faintly alkaline egg-white. Faintly acid egg-white is more protective against the haemolysis of guineapig's corpuscles by fresh rabbit's serum than is slightly alkaline egg-white.

(15) In view of the results here recorded, it appears premature to accept any of the current hypotheses concerning haemolysis either by saponin or by haemolytic sera. Indications are, however, forthcoming that physical processes play a part in the inception of haemolysis by saponin.

\section{REFERENCES.}

Barker (1922). A Text Book of Clinical Medicine, p. 269. Philadelphia.

Bayliss (1906). Biochem. J. 1, 175.

Buchanan (1919). J. Bact. 4, 85.

Eisler (1909). Z. Immunitätsf. 2, 159.

Fenn (1922). J. Exp. Med. 35, 271.

Holker (1923). Proc. Roy. Soc. Lond. A. $102,710$.

Kerner (1910). Russki Vratsch. 9, Nos. 34-35.

Kuno (1918). Tokyo Zasshi, 32, Nos. 1-36.

Moore, Wilson and Hutchinson (1909). J. Physiol. 38; Proc. Mar. 27th.

Pickering and Collins (1923). J. Physiol. 57; Proc. Jan. 20th.

Ponder (1921), Proc. Roy. Soc. Lond. B. 92, 285.

- (1922). Proc. Roy. Soc. Lond. B. 93, 86.

- (1923). Proc. Roy. Soc. Lond. B. 95, 42.

Purdy and Walbum (1922). J. Immunology, 7, 35.

Schmidt and Norman (1920). J. Infect. Dis. 27, 40.

Sutherland and Mitra (1916). Indian J. Med. Res. 4, 698. 